\title{
Growth Performance and Physiological Status of Intensively raised West African Dwarf (WAD) Goats Supplemented with Dietary Antioxidants
}

\author{
A. O., Yusuf ${ }^{1,2 \#}$,A.A., Raheem ${ }^{2}$, O, S., Sowande ${ }^{2}$, K. O. Adebayo ${ }^{2}$, L. Motsei ${ }^{1}$ \&A.A. \\ Ayoola $^{2}$ \\ ${ }^{1}$ Department of Animal Science, School of Agriculture, Faculty of Science and \\ Technology, North West University, Mafikeng, South Africa. \\ ${ }^{2}$ Department of Animal Production and Health, Federal University of Agriculture, \\ PMB. 2240, Abeokuta, Nigeria.
}

\begin{abstract}
$\mathbf{T}$ HIS study explored the impact of dietary antioxidant supplementation on growth performance and blood profile of intensively raised West African dwarf goats. Thirty West African dwarf goats $(8.00 \pm 0.13 \mathrm{~kg})$ were divided into five treatment groups of six (6) animals per group and randomly allotted to one of the five diets supplemented with (1). no dietary antioxidant (control); (2). Vitamin E (200mg/kg of feed); (3).Vitamin C (600 $\mathrm{mg} / \mathrm{kg}$ of feed); (4). $200 \mathrm{mg}$ Vitamin E+ 0.2mg Selenium/kg of feed; (5). $600 \mathrm{mg}$ Vitamin C+ $0.2 \mathrm{mg}$ Selenium/ $\mathrm{kg}$ of feed respectively, in a completely randomized design. The results revealed that dietary antioxidant supplementation significantly $(\mathrm{p}<0.05)$ influenced the red blood cell $(\mathrm{RBC})$ with higher values in selenium supplemented groups, white blood cell (WBC) and basophil counts. Albumin, glucose and alanine transaminase (ALT) significantly $(\mathrm{p}<0.05)$ differed across the diets. The significantly $(\mathrm{p}<0.05)$ reduced thiobabutiric acid substance (TBARS) in supplemented groups compared to the control justified the scavenging characteristics of the supplemented antioxidants. Furthermore, cholesterol, uric acid, glutathione (GSH), glutathione S -tranferase (GST) and superoxide dismutase (SOD) activities were oxidative biomarkers significantly $(\mathrm{p}<0.05)$ influenced by the antioxidants supplementation while bilirubin and Vitamin $\mathrm{E}$ were similar across the treatments. The findings of this study revealed that Vitamin E, Vitamin C and their combination with Selenium did not only enhance erythrocyte formation but improved immune response and health status as well as the oxidative status of the goats by reducing the activities of TBARS and increasing the activities of SOD, GSH and GST.
\end{abstract}

Keywords:Antioxidants, growth performance, immune response, West African Dwarf goat.

\section{Introduction}

To meet the increasing demand for animal products due to the rapid human population growth small ruminant production has been shifted from the normal extensive and/or semiintensive production system to the intensive production system. However, intensive system of production hampers health and welfare of the animals [1-4]. Consequently, this increased the incidence of metabolic and infectious diseases [5,6]. Animal welfare impacts from compulsory intensive system of farming are enormous. They vary from discomfort and injuries which can be linked to inappropriate flooring and housing, prevention of normal maternal behaviour, social stress and injuries caused by overcrowding. Also, health issues resulting from extreme selective breeding and management for optimum growth and high efficiency as well as fast-spreading infections encouraged by crowding and stress are resultant effect of intensive rearing etc. These, suffice to indicate the absence of good welfare in commercial livestock production [7].

Impaired welfare of the animals leads to breakdown of the immune system as a result of excessive production of reactive oxygen molecules (ROM) more than the cellular anti-oxidant system (immune system) can counteract. The main physiological processes like growth, pregnancy, lactation and environmental factors increase production of these free radicals and/or decrease antioxidant activity. Hence, in order to combat excessive production of reactive oxygen molecules, there is need for effective antioxidant system [8]. 
Vitamin C, Vitamin E and Selenium combination were used to improve the growth and reproductive performance of WAD goat by protecting the biological membranes against the damage of $\operatorname{ROM}[6,9,10]$. It is therefore hypothesize that dietary antioxidants supplementation in goats will improve their growth performance characteristics, blood profile and immune system. This study aimed to highlight the influence of dietary antioxidants supplementation in intensive housing systems through enhanced growth performance, improved blood profile and reduction of oxidative stress in West African Dwarf goats.

\section{Materials and Method}

The experiment was conducted at the Small Ruminant Unit, Directorate of University Farm, Federal University of Agriculture, Abeokuta, Ogun State. The site is a rain forest vegetation zone of Southern - Western Nigeria on Latitude $7^{\circ} 13^{\prime}$ $49.46^{\prime \prime} \mathrm{N}$, longitude $3^{\circ} 26^{\prime} 11.98$ " E and altitude of $76 \mathrm{~m}$ above the sea level. The experiment was done after the approval of the proposal by the animal welfare group at the College of Animal Science and Livestock Production, Federal University of Agriculture, Abeokuta, Nigeria (ethical clearance number COLANIM/APH/PG/0080/10).
Thirty growing West African Dwarf (WAD) goats with an average weight of $8.00 \pm 0.13 \mathrm{~kg}$ were used for the experiment. They were sourced from villages (Kinlehin and Elepa village) around Federal University of Agriculture, Abeokuta, Nigeria. The goats were housed individually in an experimental pen with aluminum roofing sheet and a raised slatted floor. The experimental pens were properly cleaned and sanitized with Morigad $^{\circledR}$ disinfectant one week before the arrival of the animals. The animals were allowed four weeks adjustment period, 3 weeks adjustment period to the experimental pen and a week to the experimental diets. They were treated against mange and other parasites using ivermectin injection whereas, oxytetracycline $20 \%$ and Penstrep (penicillin and streptomycin) were injected as prophylaxis against bacterial infections.

Cassava peels were purchased from garri processing industry at Camp, Abeokuta, Ogun State and sun dried for five days. Wheat offal, maize, maize bran, palm kernel cake (PKC), bone meal, oyster shell, and salt were obtained from Jeje feed mill in Abeokuta, Ogun state. The ingredients were ground and mixed together to form concentrate diet (Table 1).

TABLE 1. Ingredient composition of experimental diet (\%).

\begin{tabular}{|c|c|c|c|c|c|c|}
\hline \multirow[b]{2}{*}{ Ingredients (\%) } & \multicolumn{5}{|c|}{ Proximate composition } & \multirow[b]{2}{*}{$\begin{array}{c}\text { Enterolobiumcy } \\
\text { clocarpum }\end{array}$} \\
\hline & $\mathbf{0}$ & $\mathbf{E}$ & $\mathbf{C}$ & $\mathrm{E} / \mathrm{Se}$ & $\mathrm{C} / \mathrm{Se}$ & \\
\hline Maize & 10.00 & 10.00 & 10.00 & 10.00 & 10.00 & - \\
\hline PKC & 25.00 & 25.00 & 25.00 & 25.00 & 25.00 & - \\
\hline Cassava Peel & 30.00 & 30.00 & 30.00 & 30.00 & 30.00 & - \\
\hline Wheat Offal & 30.00 & 30.00 & 30.00 & 30.00 & 30.00 & - \\
\hline Bone Meal & 2.00 & 2.00 & 2.00 & 2.00 & 2.00 & - \\
\hline Oyster Shell & 2.00 & 2.00 & 2.00 & 2.00 & 2.00 & - \\
\hline Salt & 1.00 & 1.00 & 1.00 & 1.00 & 1.00 & - \\
\hline Vitamin E & - & + & - & - & - & - \\
\hline Vitamin C & - & - & + & - & - & - \\
\hline Vitamin E/Selenium & - & - & - & + & - & - \\
\hline Vitamin C/Selenium & - & - & - & - & + & - \\
\hline Total & 100 & 100 & 100 & 100 & 100 & - \\
\hline \multicolumn{7}{|l|}{ Determined Analysis (\%) } \\
\hline Dry matter & 88.73 & 89.03 & 89.34 & 88.91 & 88.77 & 37.79 \\
\hline Crude Protein & 12.65 & 11.51 & 12.57 & 12.60 & 12.65 & 19.71 \\
\hline Crude fibre & 6.52 & 7.10 & 6.98 & 7.15 & 6.77 & N.D \\
\hline Ether extract & N.D & N.D & N.D & N.D & N.D & 2.28 \\
\hline Ash & N.D & N.D & N.D & N.D & N.D & 7.06 \\
\hline Neutral detergent fibre & N.D & N.D & N.D & N.D & N.D & 49.9 \\
\hline Acid detergent fiber & N.D & N.D & N.D & N.D & N.D & 30.54 \\
\hline Acid detergent lignin & N.D & N.D & N.D & N.D & N.D & 21.68 \\
\hline Metabolizable Energy $(\mathrm{MJ} / \mathrm{kg})$ & 26.82 & 27.32 & 27.02 & 27.43 & 26.97 & N.D \\
\hline
\end{tabular}

0: No dietary antioxidant, E: $200 \mathrm{mg} / \mathrm{kg}$ of feed Vitamin E, C: $600 \mathrm{mg} / \mathrm{kg}$ of feed Vitamin C, E/Se: $200 \mathrm{mg} / \mathrm{kg}$ of Vitamin $\mathrm{E}+0.2 \mathrm{mg} / \mathrm{kg}$ of feed Selenium, C/Se: $600 \mathrm{mg} / \mathrm{kg}$ of Vitamin C $+0.2 \mathrm{mg} / \mathrm{kg}$ of feed Selenuim

N.D: Not determined

Egypt. J. Vet. Sci. Vol. 50, No.1 (2019) 
The concentrate diet was supplemented with antioxidants as follow, the control group received no dietary antioxidant, the second group received $200 \mathrm{mg} / \mathrm{kg}$ of Vitamin E, the third group received $600 \mathrm{mg} / \mathrm{kg}$ of Vitamin $\mathrm{C}$, the fourth one received $200 \mathrm{mg} / \mathrm{kg}$ of Vitamin $\mathrm{E}+0.2 \mathrm{mg} / \mathrm{kg}$ of Selenium and the last group received $600 \mathrm{mg} / \mathrm{kg}$ of Vitamin C $+0.2 \mathrm{mg} / \mathrm{kg}$ Selenuim $[11,12]$. The thirty (30) goats were divided into 5 treatment groups of six (6) animal per group and randomly allotted to the five dietary treatments in a completely randomize design. The experiment lasted for 90 days. The goats were offerd the concentrates diets at $4 \%$ of their body weight while Enterelobium cyclocarpum leaves were fed to satiation and water was available at all the time.

Weight changes was determined by weighing the goats weekly using digital scale at the onset of the experiment after withdrawal of feed overnight (to avoid gut filled weight of the animals). Daily feed intake was measured by subtracting the feed refused from the feed supplied. The weights were taken in the morning at 07:00 hour before feeding. Feed conversion ratio (FCR) was calculated by dividing the feed intake (FI) by body weight gain.

Twelve milliliters $(12 \mathrm{ml})$ of blood was collected via the jugular vein of each animal using hypodermic needle and syringe at the end of the experiment. Four $(4 \mathrm{ml})$ of the sample was released into the sample bottles containing Ethylenediaminetetraacetic acid (EDTA) as anticoagulant and analysed [13] for haematological parameters (Packed cell volume, haemoglobin, white and red blood cell counts and white blood cell differentials). The remaining $8 \mathrm{ml}$ of blood samples were divided into two separate plain sample bottles without anti-coagulant to harvest serum. Serum glucose, total protein, albumin, globulin, alanine aminotransferase, aspartate aminotransferase, cholesterol, bilirubin and urea were immediately analysed using automated spectrophotometer. Superoxide dismutase activity was determined by the method of Janknegt and colleagues [14]. The activity of glutathione and glutathione-S-transferase were determined by the method of Pascual et al. [15], while thiobarbituric acid substance (TBARS) was determined using the method of Buege and Aust [16].

Data were subjected to one-way Analysis of Variance as contained in Statistical Package for Social Science [17]. Significant means $(P<0.05)$ were separated using the New Duncan's multiple range test.

\section{$\underline{\text { Results }}$}

The performance characteristics of West African Dwarf (WAD) goats as affected by the dietary antioxidant supplementation is presented in Table 2.

TABLE 2 . Growth performance characteristics of WAD goats fed dietary antioxidants.

\begin{tabular}{|c|c|c|c|c|c|c|c|}
\hline${ }^{1}$ Parameters & Control & $\begin{array}{c}\text { Vitamin } \\
\text { E }\end{array}$ & $\begin{array}{c}\text { Vitamin } \\
\text { C }\end{array}$ & $\begin{array}{l}\text { Vitamin E/ } \\
\text { Selenium }\end{array}$ & $\begin{array}{l}\text { Vitamin C/ } \\
\text { Selenium }\end{array}$ & SEM & P-Value \\
\hline Initial weight (kg) & 7.95 & 8.13 & 7.97 & 7.89 & 7.89 & 0.27 & 0.97 \\
\hline Final weight $(\mathrm{kg})$ & $12.73^{\mathrm{a}}$ & $11.96^{\mathrm{a}}$ & $11.95^{\mathrm{a}}$ & $11.71^{\mathrm{a}}$ & $10.11^{\mathrm{b}}$ & 0.35 & 0.00 \\
\hline Weight gain (kg) & $4.84^{\mathrm{a}}$ & $3.83^{\mathrm{a}}$ & $3.98^{\mathrm{a}}$ & $3.82^{\mathrm{a}}$ & $2.22^{b}$ & 0.46 & 0.01 \\
\hline $\begin{array}{l}\text { Metabolic weight } \\
\left(\mathrm{kgBW}^{0.75}\right)\end{array}$ & $3.25^{\mathrm{a}}$ & $2.71^{\mathrm{a}}$ & $2.80^{\mathrm{a}}$ & $2.71^{\mathrm{a}}$ & $1.79^{\mathrm{b}}$ & 0.25 & 0.01 \\
\hline Weight gain (g/day) & $49.40^{\mathrm{a}}$ & $39.06^{\mathrm{a}}$ & $40.60^{\mathrm{a}}$ & $38.93^{\mathrm{a}}$ & $22.65^{\mathrm{b}}$ & 4.69 & 0.01 \\
\hline Conc. DMI(g/day) & $332.07^{\mathrm{a}}$ & $315.35^{\mathrm{a}}$ & $314.20^{\mathrm{a}}$ & $309.66^{\mathrm{a}}$ & $254.12^{\mathrm{b}}$ & 16.76 & 0.03 \\
\hline Forage DMI (g/day) & $264.64^{\mathrm{a}}$ & $264.23^{\mathrm{a}}$ & $266.72^{\mathrm{a}}$ & $265.29^{\mathrm{a}}$ & $262.11^{\mathrm{b}}$ & 4.53 & 0.05 \\
\hline TDMI (g/day) & 596.71 & 564.36 & 580.91 & 574.94 & 516.24 & 26.42 & 0.29 \\
\hline FCR & $12.33^{\mathrm{b}}$ & $15.04^{\mathrm{b}}$ & $14.70^{\mathrm{b}}$ & $16.65^{\mathrm{b}}$ & $22.83^{\mathrm{a}}$ & 1.36 & 0.00 \\
\hline
\end{tabular}


The final weight $(\mathrm{kg})$, weight gain in $(\mathrm{kg})$, daily weight gain (g/day), metabolic weight gain $(\mathrm{kg}$ $\mathrm{BW}^{\wedge} 0.75$ ), forage dry matter intake, concentrate dry matter intake and feed conversion ratio were differed $(P<0.05)$ across the dietary treatment. However, the total dry matter intake were not influenced $(P>0.05)$ by the dietary antioxidants supplementation. Animals supplemented with Vitamin $\mathrm{C} /$ Selenium had the poorest values for most of the parameters, however, the values among other group of animals were similar $(P>0.05)$.

Table 3 shows the haematological parameters and white blood cell differentials of West African Dwarf goat fed antioxidants' supplemented diets. Vit. E-Se and Vit C-Se supplementation increased $(P<0.05)$ the red blood cell $(\mathrm{RBC})$ while the white blood cell (WBC) count were decreased $(P<0.05)$. On the other hand, similar values $(P>0.05)$ were recorded for packed cell volume (PCV) and haemoglobin (hb) concentration. Goats fed Vitamin E-selenium (Vit E/Se) and Vitamin $\mathrm{C}$-selenium (Vit $\mathrm{C} / \mathrm{Se})$ had significantly $(P<0.05)$ higher RBC values $\left(7.40 \times 10^{12 / L}\right.$ and $7.48 \times 10^{12 / L}$, respectively) than other treatment groups. The highest $\left(10.40 \times 10^{9 / \mathrm{L}}\right)$ WBC was observed for animals fed Vit E. Moreover, supplementation of $\mathrm{Vit} \mathrm{E} / \mathrm{Se}$ gave a reduced $(P<0.05)$ basophil concentration with the control group have the highest $(P<0.05)$ basophil concentration. Neutrophil, lymphocyte, eosinophil and monocyte were comparable $(P>0.05)$ across the dietary treatments.

The serum biochemical parameters of the experimental goats are presented in Table 4 .

Albumin, glucose and alanine transaminase (ALT) concentration were differed $(P<0.05)$ across the treatments. Animals fed control diet had the highest mean glucose value $(94.78 \mathrm{mg} / \mathrm{dl})$ with the least mean value $(60.50 \mathrm{mg} / \mathrm{dl})$ for glucose observed in animals supplemented with Vit C. Total protein, globulin and aspartate transaminase (AST) values were similar $(P>0.05)$ across the treatment groups. Vit C-Se supplementation indicated high blood ALT concentration (30.00 $\mathrm{u} / \mathrm{l})$ while those fed Vit E had the least blood ALT $(21.67 \mathrm{u} / \mathrm{l})$.

Table 5 presents the oxidative stress biomarkers in the experimental animals.

TABLE 3 .Haematological and white blood cell differencials as affected by dietary antioxidants supplementatin.

\begin{tabular}{|c|c|c|c|c|c|c|c|}
\hline${ }^{1}$ Parameters & Control & Vitamin E & Vitamin C & $\begin{array}{l}\text { Vitamin E/ } \\
\text { selenium }\end{array}$ & $\begin{array}{l}\text { Vitamin C/ } \\
\text { selenium }\end{array}$ & SEM & P-Value \\
\hline \multirow{2}{*}{\multicolumn{8}{|c|}{$\begin{array}{l}\text { Haematological } \\
\text { parameters }\end{array}$}} \\
\hline & & & & & & & \\
\hline PCV (\%) & 39.75 & 37.00 & 33.92 & 36.25 & 39.00 & 3.58 & 0.80 \\
\hline $\begin{array}{l}\text { Haemoglobin } \\
(\mathrm{g} / \mathrm{dl})\end{array}$ & 12.56 & 11.60 & 10.56 & 11.48 & 12.55 & 0.61 & 0.16 \\
\hline $\operatorname{RBC}\left(\times 10^{12 / L}\right)$ & $6.63^{\mathrm{ab}}$ & $6.43^{\mathrm{ab}}$ & $5.75^{\mathrm{b}}$ & $7.40^{\mathrm{a}}$ & $7.48^{\mathrm{a}}$ & 0.54 & 0.05 \\
\hline WBC $\left(\times 10^{9 / \mathrm{L}}\right)$ & $7.42^{\mathrm{b}}$ & $10.40^{\mathrm{a}}$ & $9.10^{\mathrm{ab}}$ & $8.10^{\mathrm{b}}$ & $7.58^{\mathrm{b}}$ & 0.55 & 0.01 \\
\hline \multirow{2}{*}{\multicolumn{8}{|c|}{$\begin{array}{l}\text { White blood cell } \\
\text { differentials }\end{array}$}} \\
\hline & & & & & & & \\
\hline Neutrophil (\%) & 31.00 & 27.00 & 33.75 & 32.67 & 34.75 & 2.58 & 0.31 \\
\hline Lymphocyte (\%) & 65.50 & 69.33 & 64.00 & 62.92 & 63.75 & 2.08 & 0.40 \\
\hline Eosinophil (\%) & 0.75 & 1.00 & 1.00 & 0.25 & 0.00 & 0.22 & 0.07 \\
\hline Basophil (\%) & $1.25^{\mathrm{a}}$ & $0.75^{\mathrm{ab}}$ & $0.33^{\mathrm{ab}}$ & $0.00^{\mathrm{b}}$ & $1.00^{\mathrm{ab}}$ & 0.29 & 0.05 \\
\hline Monocyte (\%) & 1.50 & 1.50 & 1.00 & 1.00 & 0.50 & 0.53 & 0.58 \\
\hline
\end{tabular}

a, $\mathbf{b}, \mathbf{c}$ : Means on the same row with different superscripts are statistically different $(p<0.05)$

1. PCV: packed cell volume, RBC: red blood cell, WBC: white blood cell

Egypt. J. Vet. Sci. Vol. 50, No.1 (2019) 
TABLE 4. Serum biochemical components of West African dwarf goats offered dietary antioxidants.

\begin{tabular}{lccccccc}
\hline \multicolumn{1}{c}{ 1 Parameters } & Control & Vitamin E & Vitamin C & $\begin{array}{c}\text { Vitamin E/ } \\
\text { selenium }\end{array}$ & $\begin{array}{c}\text { Vitamin C/ } \\
\text { selenium }\end{array}$ & SEM & P-Value \\
\hline Total protein (g/dl) & 5.98 & 5.77 & 5.78 & 5.76 & 6.08 & 0.32 & 0.94 \\
Albumin (g/dl) & $3.30^{\mathrm{ab}}$ & $3.23^{\mathrm{b}}$ & $3.15^{\mathrm{b}}$ & $3.15^{\mathrm{b}}$ & $3.88^{\mathrm{a}}$ & 0.20 & 0.04 \\
Globulin (g/dl) & 2.78 & 3.53 & 3.63 & 3.60 & 3.90 & 0.27 & 0.89 \\
Glucose (mg/dl) & $94.78^{\mathrm{a}}$ & $82.33^{\mathrm{ab}}$ & $60.50^{\mathrm{b}}$ & $66.25^{\mathrm{b}}$ & $84.50^{\mathrm{ab}}$ & 7.63 & 0.04 \\
AST (u/l) & 60.25 & 58.00 & 56.50 & 56.25 & 59.25 & 3.16 & 0.88 \\
ALT $(\mathrm{u} / \mathrm{l})$ & $27.75^{\mathrm{ab}}$ & $21.67^{\mathrm{b}}$ & $24.50^{\mathrm{ab}}$ & $24.00^{\mathrm{ab}}$ & $30.00^{\mathrm{a}}$ & 2.11 & 0.05 \\
\hline a,b, $:$ Means on the same row with different superscripts are statistically different $(\mathrm{p}<0.05)$ & & & \\
${ }^{1}$ AST: Aspertaseaminotransaminase, ALT: Alanine aminotransferase & & &
\end{tabular}

TABLE 5. Effect of dietary antioxidant supplementation on oxidative stress biomarkers of West African dwarf goats.

\begin{tabular}{lccccccc}
\hline${ }^{1}$ Parameters & Control & Vitamin E & Vitamin C & $\begin{array}{c}\text { Vitamin E/ } \\
\text { selenium }\end{array}$ & $\begin{array}{c}\text { Vitamin C/ } \\
\text { selenium }\end{array}$ & SEM & P-Value \\
\hline TBARS $(\mathrm{nM})$ & $455.13^{\mathrm{a}}$ & $435.90^{\mathrm{ab}}$ & $258.01^{\mathrm{ab}}$ & $346.75^{\mathrm{ab}}$ & $243.59^{\mathrm{b}}$ & 44.614 & 0.05 \\
GSH $(\mathrm{nM})$ & $2.21^{\mathrm{b}}$ & $1.87^{\mathrm{b}}$ & $2.10^{\mathrm{b}}$ & $3.56^{\mathrm{a}}$ & $2.16^{\mathrm{b}}$ & 0.410 & 0.00 \\
GST $(\mathrm{U} / \mathrm{mL})$ & $0.0093^{\mathrm{a}}$ & $0.0086^{\mathrm{a}}$ & $0.0059^{\mathrm{b}}$ & $0.0046^{\mathrm{b}}$ & $0.0052^{\mathrm{b}}$ & 0.0006 & 0.00 \\
SOD $(\mathrm{U} / \mathrm{mL})$ & $1.70^{\mathrm{b}}$ & $1.45^{\mathrm{b}}$ & $1.17^{\mathrm{b}}$ & $3.61^{\mathrm{a}}$ & $2.00^{\mathrm{b}}$ & 0.366 & 0.01 \\
Cholesterol $(\mathrm{mg} / \mathrm{dl})$ & $74.25^{\mathrm{ab}}$ & $57.00^{\mathrm{b}}$ & $80.50^{\mathrm{a}}$ & $70.75^{\mathrm{ab}}$ & $79.25^{\mathrm{ab}}$ & 6.762 & 0.05 \\
Uric acid & $4.10^{\mathrm{ab}}$ & $4.03^{\mathrm{b}}$ & $5.12^{\mathrm{a}}$ & $4.73^{\mathrm{ab}}$ & $4.23^{\mathrm{ab}}$ & 0.321 & 0.04 \\
Bilirubin & 0.25 & 0.43 & 0.33 & 0.30 & 0.40 & 0.101 & 0.80 \\
VIT E $(\mu \mathrm{g} / \mathrm{ml})$ & 9.09 & 7.81 & 8.26 & 8.97 & 7.76 & 1.043 & 0.17 \\
\hline a,b $:$ Means on the & & & & & & &
\end{tabular}

a,b: Means on the same row with different superscripts are statistically different $(\mathrm{p}<0.05)$

${ }^{1}$ TBARS: Thiobabutiric acid substance, GSH: Glutathione, GST: Glutathione-s-tansferase, SOD: Superoxide dismutase,

Most of the antioxidants parameters considered were differed $(P<0.05)$ as influenced by the supplemented antioxidants. However, bilirubin and Vit E were comparable $(P>0.05)$ across the treatment groups. Goats fed Vit $\mathrm{C}$ and Vit $\mathrm{C} / \mathrm{Se}$ ) supplemented diet had the lowest thiobabutiric acid substance (TBARS) concentrations (258.01 and $243.59 \mathrm{nM}$, respectively) with control animals exhibiting the highest (455.1282 $\mathrm{nM}$ ). Vit E-Se supplemented group had the highest $(P<0.05) \mathrm{GSH}$ value $(3.56 \mathrm{nM})$ compared to Vit E group which had the lowest mean value (1.87 $\mathrm{nM})$. Compared to Vit C $(0.0059 \mathrm{U} / \mathrm{mL})$, Vit E-Se $(0.0046 \mathrm{U} / \mathrm{mL})$ and Vit $\mathrm{C} / \mathrm{Se}(0.0052 \mathrm{U} /$ $\mathrm{mL})$, control $(0.0096 \mathrm{U} / \mathrm{mL})$ and Vit E $(0.0086$ $\mathrm{U} / \mathrm{mL}$ ) had higher GST mean values. Addition of Se to Vit $\mathrm{E}$ while Vit $\mathrm{C}$ gave higher mean SOD values (3.6098 and $2.0048 \mathrm{U} / \mathrm{mL}$, respectively) compared to animals supplemented with Vit E $(1.4548 \mathrm{U} / \mathrm{mL})$ and Vit C $(1.1655 \mathrm{U} / \mathrm{mL})$ alone. The cholesterol level ranged from $57.75 \mathrm{mg} / \mathrm{dl}$ in Vitamin E group to $80.50 \mathrm{mg} / \mathrm{dl}$ in Vitamin C group. Dietary supplementation of Vit $\mathrm{C}$ reflected the highest mean value $(5.12 \mathrm{mg} / \mathrm{dl})$ for uric acid while Vit E supplementation gave the least mean value $(4.03 \mathrm{mg} / \mathrm{dl})$.

\section{Discussion}

Rearing goats outside their natural environment hinders their attainment of full production potential due to impairment of their welfare through the breakdown of immune system [18]. Supplementation with antioxidants including Vit E, C and selenium help in Egypt. J. Vet. Sci. Vol. 50, No.1 (2019) 
building antioxidant system in the body of an animal. Dietary antioxidant increased growth performance characteristics [19]. In contrast, comparable growth performance characteristics were observed for most of the supplemented groups and the control group in this present study. However, it was reported higher final weight gain and daily gain in the supplemented group compared with the control group [20]. Furthermore, their report was also in contrast to the results of this study in terms of Vit $\mathrm{C}$ versus the control group. It also corroborated with a similar study where Vit E supplementation which had no influence on the growth performance of male 'Tan' Sheep lambs [21]. In agreement with this study, it was noted that Vit E supplementation had beneficial effect on performance of young animals [22]. Moreover, addition of Vit E, Vit C and Vit E/Se compete well with the control diet in terms of weight gain and feed intake when compared to supplementation of Vit C-Se. hence, addition of Vit E, Vit C and Vit E-Se will have no detrimental effect on growth performance of West African dwarf goats.

The significantly higher RBC for those receiving Vit E-Se and Vit CSe confirms the synergistic effect of combination of antioxidants in a single diet most especially Vit E-Se. This also justifies the lower RBC obtained in Vit C, control and Vit $\mathrm{E}$ groups. This result reveals the essentiality of antioxidants supplementation in boosting the erythrocyte concentration of the blood. The pressing need for antioxidant supplementation in goat diet to maintain normal antioxidants' balance in the circulatory system [23]. Antioxidant pool in the blood aid the scavenging action of RBC towards the reactive oxygen molecules and reactive nitrogen species, however, in low antioxidant tissue, RBC defenses will be counteract by the excess prooxidants. Similar study [24] indicated significant increase in total RBC in selenium supplemented sheep. The result of WBC is also in accordance to the work of other researcher [19] who reported a significant relationship between lambs injected with Vitamin E and Selenium, and those injected with normal saline solution. Normal physiological range $\left(4-13 \times 10^{9 / \mathrm{L}}\right)$ of WBC indicated that the supplemented antioxidant had no deleterious effect on the goat's immune response. The physiological range observed for WBC could be related to normal protection of cell membrane and intracellular organelles by the dietary antioxidants. This indicated that the supplemented antioxidant will ensure normal protective and defensive function of leukocyte against any external influence.

In contrast to the result of this study, a comparable relationship was reported in basophil count for both supplemented and control group [19]. It is believed that supplementation of antioxidants aided the regulation of adaptive immune response and mast cells in response to allergens and parasite infection [25]. The free radical trapping activities of albumin, an abundantly circulating antioxidant is modified by several physiological and pathological situations [26]. This circumstances explained the irregularities in albumin concentration observed in this study. Acute and chronic inflammatory diseases may increased blood globilin levels as a result of the activation of the host inflammatory responses [27]. Increased globulins has been reported in sheep naturally infected with Babesia ovis and calves affected by respiratory diseases $[28,29]$. Total plasma protein, albumin and globulin levels decrease in goats subjected to stress [30]. The increased globulins observed with antioxidants supplementated group affirms the humoral immunity and electropholitic mobility actions of the supplemented antioxidants especially Vitamin E/Se.

Total serum cholesterol is an indicator for increasing levels of free radical damage in the body. Increased cholesterol produced internally from liver act as antioxidant to scavenge excess free radical production within the body [31]. Normal cholesterol value for sheep and goats reported by Merck [32] ranged between 65$136 \mathrm{mg} / \mathrm{dL}$, experimental goats were within the reported range except those treated with Vitamin E. The lower cholesterol level observed for Vitamin E supplemented group to that report from Merk might be due to breed or environmental differences. However, the cholesterol value in Vit E supplemented group was within the 42.7-70.19 $\mathrm{mg} / \mathrm{dL}$ range reported for clinically healthy West African dwarf goats [33].

Inefficient scavenging of reactive oxygen species may cause both oxidative liver damage and increased liver enzyme activity [34], therefore making enzyme levels a reflector of metabolic activities during stress. The significantly lower ALT in antioxidant supplemented groups except Vit C-Se when compared to the control group indicated that antioxidants supplementation reduced stress in the experimental animals as 
AST and ALT values have been reported to be higher in stressed goats [35]. However, the significantly higher value recorded in Vit $\mathrm{C} / \mathrm{Se}$ group was still within the normal clinical range for health reported by some researchers $[32,36]$. Manifestation of the antioxidant effect of uric acid requires the presence of ascorbic acid [37]. Uric acid concentration in Vit $\mathrm{C}$ supplemented group was significantly higher than all other treatment groups, hence, substantiates the above report. Normal blood cells have the ability to detoxify superoxide radicals using antioxidant enzymes (superoxide dismutase, glutathione peroxidase, and catalase) and non-enzymatic antioxidants including vitamins (C, and $\mathrm{E})$, and proteins (albumin, glutathione) [38].

However, studies had it that supplementation of dietary antioxidants go a long way to improve the antioxidant capacity of livestock animals [39-41], especially when exposed to stress. The significantly higher SOD value in selenium supplemented groups corroborates other studies [42] where significant increase in SOD activities of goats supplemented with selenium was reported. This increase in SOD activity was attributed to an elevated liver MnSOD [43]. This is an indication that selenium does have an effect on blood SOD activities. Also, this further confirms the synergism action of Vitamin $\mathrm{E}$ and Selenium [44,45]. Although, the values obtained for Vit C-Se is comparable to other treatment groups, the numerically higher value noted indicated that the combination of Vitamin $\mathrm{C}$ and Selenium still serve as good antioxidant. The antioxidant capacity of the supplemented antioxidant is further reflected in the reduced MDA in the supplemented group. MDA is formed during lipid peroxidation caused by oxidative damage [46]. The aldehyde groups of MDA is assumed to act as an anchor between sugar and protein moieties, therefore led to the formation of glycated proteins [47]. In-vitro experiments have indicated that antioxidants such as vitamin $\mathrm{C}$ and glutathione is important to curb the process of protein glycation [48]. Also, vitamin C has been documented to prevent glycosylation of proteins [49]. This findings elucidates the lower MDA values in most supplemented antioxidant compared to the control.

The reported decrease in GST activities in selenium supplemented group is in agreement with the result of other studies [42]. Information about the effect of antioxidants on serum or plasma GST activity in ruminant livestock is scanty in literature. Elevated GST levels has been associated with increased resistance to oxidative damage. moreover, little or no information is available to establish the direct effect of GST reactions in combating oxidative stress [50]. However, the reduced level of GST observed in this present experiment can be attributed to the promiscuity of GST enzymes as they can catalyse several reactions and react with various substrates. Suffice to say, it is highly reactive and actively involved in many protective activities in body metabolism [51].

Dietary antioxidants play significant role in improving immunity, antioxidant status and reproduction in animals. Selenium (Se) is essential in the development and expression of non-specific humoral and cell mediated immune responses. According to [52], Se supplementation can indirectly improve performance by strengthening the immunity of the animals $[52,53]$. This supports the higher RBC values recorded for selenium supplemented groups in this study.

\section{Conclusion}

Dietary antioxidants (Vit E, Vit C and their individual combination with selenium) dispay similar growth performance of WAD goats. However, combination of Vit $\mathrm{C}+\mathrm{Se}(200 \mathrm{mg}+$ $0.2 \mathrm{mg} / \mathrm{kg}$ of feed $)$ and Vit $\mathrm{E}+\mathrm{Se}(600 \mathrm{mg}+0.2 \mathrm{mg} /$ $\mathrm{kg}$ of feed) enhanced erythrocyte formation. It also improved the immune response and health status of the animals in terms of elevated albumin and SOD with resultant reduction in the thiobabituric substances and bilirubin of the intensively raised West African dwarf (WAD) goats.

\section{Conflict of Interest Declaration}

There is no conflict of interest in the course of this research.

\section{References}

1. Dawkins M.S. From an animal's point of view: motivation, fitness, and animal welfare. Behav. Brain Sci. 13, 1-61 (1990).

2. Jensen, P. and Toates, F.M. Who needs 'behavioural needs'? Motivational aspects of the needs of animals. Appl Ani Behav Sci. 37(2), 16181 (1993).

3. Špinka, M. How important is natural behaviour in animal farming systems. Appl Ani Behav Sci. 100(1-2):117-28 (2006).

Egypt. J. Vet. Sci. Vol. 50, No.1 (2019) 
4. Broglio, R.S. Animal welfare in science and society. Food Safety Assurance and Veterinary Public Health. 5, 45-58 (2009).

5. Henry, B., Charmley, E., Eckard, R., Gaughan, J.B. and Hegarty, R. Livestock production in a changing climate: adaptation and mitigation research in Australia. Crop Pasture Sci. 63, 191202 (2012)

6. Celi, P. and Chauhan, S.S.. Oxidative stress management in farm animals: opportunities and challenges. In Proceedings of the 4th International Conference on Sustainable Animal Agriculture for Developing Countries (SAADC). 95-109, (2013).

7. Na-Lampang, P. Role of Animal Welfare in Sustainable Development of Livestock Industry. In The 4th International Conference nn Sustainable Animal Agriculture For Developing Countries (SAADC2013). Pp. 77 (2013).

8. Miller, J. K., Brzezinska-Slebodzinska, E. and Madsen, F.C. Oxidative stress, antioxidants, and animal function. J Dairy Sc. 76, 2812-2823 (1993).

9. Traber, M.G. and Stevens, J.F. Vitamins C and E: beneficial effects from a mechanistic perspective. Free Radic Bio \& Med. 51(5): 10001013 (2011)

10. Nimse, S.B. and Pal, D. Free radicals, natural antioxidants, and their reaction mechanisms. RSC Advances. 5(35), 27986-28006 (2015).

11. NRC. 1981. Nutrient Requirements of Domestic Animals: Nutrient Requirements of Goats. National Academy of Sciences-National Research Council, Washington, D.C.

12. Finch, J.M., and R.J. Turner.. Enhancement of ovine lymphocyte responses: A comparison of selenium and vitamin E supplementation. Vet. Immunology and Immunopathology 23:245-249 (1989).

13. Jain, N. C. "Essentials of Veterinary Hematology, Lea and Febiger." Philadelphia, Pennsylvania (1993).

14. Janknegt, P.J., Rijstenbil, J.W., Van de Poll, W.H., Gechev, T.S. and Buma, A.G. A comparison of quantitative and qualitative superoxide dismutase assays for application to low temperature microalgae. J. Photochem. Photobiol, 87(3), 218226 (2007).
15. Pascual, P., Martinez-Lara, E., Barcena, J.A., Lopez-Barea, J. and Toribio, F. Direct assay of glutathione peroxidase activity using highperformance capillary electrophoresis. J. Chromat. B: Biomed. Sci. Appl. 581, 49-56 (1992).

16. Buege, J.A. and Aust, S.D. Microsomal lipid peroxidation. In Methods in enzymology 52, 302310. Academic Press (1978).

17. SPSS, Statistical Package for Social Scientists, SPSS for Windows, Version 15.0. New York, NY: SPSS (2006).

18. Sevi, A., Casamassima, D., Pulina, G. and Pazzona, A. Factors of welfare reduction in dairy sheep and goats. Ital Ani Sci. 8(1), 81-101 (2009).

19. Soliman, E.B. Dose-Response of Vitamin E and Selenium Injection on Growth Performance, Physiological and Immune Responses of Ossimi Lambs. Egypt J Sheep \& Goat Sci. 10(1): 27-40 (2015).

20. Hala, A.A., Abou-Zeina, N.M., Nassar, S.A. and Mohamed, A.F. Influence of dietary supplementation with antioxidants on the growth performance, hematological and serum biochemical alterations in goat kids. Global Veterinaria. 13, 926-937 (2014).

21. Zhao, T., Luo, H., Zhang, Y., Liu, K., Jia, H., Chang, Y., Jiao, L. and Gao, W. Effect of vitamin E supplementation on growth performance, carcass characteristics and intramuscular fatty acid composition of Longissimus dorsimuscle in ‘Tan'sheep. Chil JAgri Res. 73, 4 (2013).

22. Birch, K.S., Thomas, J.D. and Ross, T.T. Growth and carcass characteristics of newly received feeder lambs treated with probiotics and vitamin E. Sheep \& Goat Res.10,201-206 (1994).

23. Minetti, M., Agati, L.and Malorni, W. The microenvironment can shift erythrocytes from a friendly to a harmful behavior: pathogenetic implications for vascular diseases Cardiov Res. 75(1), 21-28 (2007).

24. Faixova, Z., Faix, S., Leng, L., Vaczi, P., Makova, Z. and Szaboova, R. Haematological, blood and rumen chemistry changes in lambs following supplementation with Se-yeast. Acta Vet-Brno, 76, 3-8 (2007).

25. Sokol, C.L. and Medzhitov, R. Role of basophils in the initiation of Th2 responses. Current Opinion in Immunl. 22(1): 73-77 (2010). 
26. Sitar, M.E., Aydin, S. and Cakatay, U. Human serum albumin and its relation with oxidative stress. J Clin Lab. 59(9-10), 945-52 (2013).

27. O'Connell T.X, Horite T.J. and Kasravi, B. Understanding and interpreting serum protein electrophoresis. Am Fam Physician. 71, 105-112 (2005).

28. Apaydin, B. and Dede, S. Electrophoretic profile of serum protein fractions from sheep naturally infected with Babesia ovis. Rev Med. Vet. 161, 57-60 (2010).

29. Tothova, C., Nag, Y.O. and Kovac, G. The serum protein electrophoretic pattern and acute phase protein concentrations in calves with chronic respiratory diseases. Acta Veterinaria Beograd 63, 473-486 (2013).

30. Helal, A., Hashem. A.L.S., Abdel - Fattah, M.S. and El-Shaer, H.M. Effects of heat stress on coat characteristics and physiological responses of Balady and Damascus goats in Sinai, Egypt. Amer.-Euras. J Agric. Environ. Sci. 7, 60-69 (2010).

31. Bansal, M.P. and Jaswal. S. Hypercholesterolemia induced oxidative stress is reduced in rats with diet enriched with supplement from dunaliella salina Algae. Am. J. Biomed. Sci. 1(3), 196-204 (2009).

32. Merck Sharp and Dohme Corp., a subsidiary of Merck \& Co., Inc. Whitehouse Station, NJ, USA (2011).

33. Yusuf, A.O., Oyebanji, O.A., Yusuf, D.A., Ekunseitan, K.A., Adeleye, O.S., Sowande, O.S. and Fasae, O.A.. Blood profile of West African dwarf goats fed Panicum maximum supplemented with Newbouldia laevis leaves. Bull Ani Hlth \& Prod. 60(4): 481-490 (2012).

34. Sanchez-Campos, S., Tunon, M.J., Gonzalez, P. and Gonzalez-Gallego, J. Oxidative stress and changes in liver antioxidant enzymes induced by experimental dicroceliosis in hamsters. J Parasitol Res. 85(6), 468-474 (1999).

35. Sharma, A.K. and Kataria, N. Effect of extreme hot climate on liver and serum enzymes in Marwari goats. Ind J Ani Sci. 81: 293-295 (2011).

36. Kaneko, J.J., Harvey, J.W. and Bruss, M.L. eds. Clinical Biochemistry of Domestic Animals. Academic press (2008).
37. Briviba, K. and Sies, H. Non-enzymatic antioxidants defence system. In: B. Frei (Ed.), Natural Antioxidants in Human Health and Disease, Academic Press, San Diego, CA, pp. 107-128, (1994).

38. Kumar, B. and Puri J.P. Influence of environmental variations on blood metabolites in buffalo. Pak $J$ Zoo. (Supplement Series) 9, 289 -291 (2009).

39. McDowell, L.R., Wilkinson, N., Madison, R., and Felix, T. Vitamins and minerals functioning as antioxidants with supplementation considerations. In the proceedings of the Florida Ruminant Nutrition Symposium. Best Western Gateway Grand. Gainesville, FL, 30-31 January (2009).

40. Sivakumar, A.V.N., Singh, G. and Varshney, V.P. Antioxidants supplementation on acid base balance during heat stress in goats. Asian-Aust $J$ Ani Sci. 23(11), 1462-1468 (2010).

41. Niu, Z.Y., Min, Y.N.and Liu, F.Z. Dietary vitamin E improves meat quality and antioxidant capacity in broilers by upregulating the expression of antioxidant enzyme genes. J Appl Ani Res. 46(1), 397-401 (2018).

42. Yue, W., Zhang, C., Shi, L., Ren, Y., Jiang, Y. and Kleemann, D.O. Effect of Supplemental Selenomethionine on Growth Performance and Serum Antioxidant Status in Taihang Black Goats. Asian-Aust J Ani Sci. 22(3): 365-370 (2009).

43. Shilo, S., Pardo, M., Aharoni-Simon, M., Glibter, S. and Tirosh, O. Selenium supplementation increases liver MnSOD expression: molecular mechanism for hepato-protection. $J$ Inorg Biochem. 102(1): 110-118 (2008).

44. Bartfay, W.J., Hou, D., Brittenham, G.M., Bartfay, E., Sole, M.J., Lehotay, D. and Liu, P.P. The synergistic effects of vitamin $E$ and selenium in iron-overloaded mouse hearts. Can. J. Cardiol. 14(7), 937-941 (1998).

45. Schwenke, D.C. and Behr, S.R. Vitamin E combined with selenium inhibits atherosclerosis in hypercholesterolemic rabbits independently of effects on plasma cholesterol concentrations. Circ Res. 83(4), 366-377 (1998).

46. Mougeot, F., Perez-Rodriguez, L., Sumozas, N. and Terraube, J. Parasites, condition, cellular immunity and carotenoid-based ornamentation in male red-legged partridge Alectoris rufa. J Avian Biol. 40, 67-74 (2009).

Egypt. J. Vet. Sci. Vol. 50, No.1 (2019) 
47. Jain, S.K. and Palmer, M. The effect of oxygen radicals metabolites and vitamin $\mathrm{E}$ on glyosylation of proteins. Free Radic. Bioll Med. 22, 593-596 (1997).

48. Stolba, P, Hatle, K, Krnakova A, Streda M. and Starka L. Effects of ascorbic acid on nonenzymatic glycation of serum proteins in vitro and in vivo. Diabetologia. 30, 529-589 (1987).

49. Huby, R. and Harding, J.J. Non-enzymatic glycosylation (glycation) of lens proteins by galactose and protection by aspirin and reduced glutathione. Exp. Eye Res. 47(1), 53-59 (1988).

50. Hayes, J.D. and Mclellan, L.I. Glutathione and glutathione-dependent enzymes represent a coordinately regulated defence against oxidative stress. Free Radic. Res. 31(4), 273-300 (1999).

51. Angelucci, F., Baiocco, P., Brunori, M., Gourlay, L., Morea, V. and Bellelli, A. Insights into the catalytic mechanism of glutathione S-transferase: the lesson from Schistosoma haematobium Structure. 13(9), 1241-1246 (2005).

52. Sobiech, P. and Kuleta, Z. Usefulness of some biochemical indicators in detection of early stages of nutritional muscular dystrophy in lambs. Small Rum Res. 45, 209-215 (2002).

53. Milad, K., Racz, O. and Sipulova, A. Effect of vitamin $\mathrm{E}$ and selenium on blood glutathione peroxidase activity and some immunological parameters in sheep. Vet Med Czech. 46, 1-5 (2001).

(Received 22/02/2019; accepted 09/05/2019) 